\title{
The Use of Intradialytic Parenteral Nutrition in Hemodialysis Patients
}

\author{
Menaka Sarav, MD, and Allon N. Friedman, $\mathrm{MD}^{2}$ \\ ${ }^{1}$ Department of Medicine, NorthShore University HealthSystem, Evanston IL \\ ${ }^{2}$ Department of Medicine, Indiana University School of Medicine, Indianapolis IN
}

Word Count: 1493

Contact corresponding author at:

Menaka Sarav, MD

Department of Medicine

Division of Nephrology and Hypertension

2650 Ridge Ave

Evanston IL 60201

Tel: $847-570-2512$

Fax: 847-570-1696

msarav@northshore.org

This is the author's manuscript of the article published in final edited form as:

Sarav, M., \& Friedman, A. N. (2018). Use of Intradialytic Parenteral Nutrition in Patients Undergoing Hemodialysis. Nutrition in Clinical Practice, 33(6), 767-771. https://doi.org/10.1002/ncp.10190 


\begin{abstract}
Intradialytic parental nutrition is a form of supplemental nutrition used to treat hemodialysis patients with malnutrition. Once the diagnosis of malnutrition is made in such patients encouragement of oral intake is the first-line treatment. If this fails, then enteral or parental nutrition may be needed. This review examines the literature on the use of intradialytic parental nutrition and summarizes the current recommendations. There is considerable controversy over indications and benefits of intradialytic parental nutrition and well-controlled, long-term studies are needed to help tease out these issues. In the interim, clinical judgment should be used when considering intradialytic parental nutrition for individual patients.
\end{abstract}




\section{BACKGROUND}

The presence of protein energy malnutrition (PEM) can be quite common ${ }^{1-3}$ among the hundreds of thousands of US hemodialysis patients and independently predicts higher hospitalization rates, lower quality of life, and death. ${ }^{4}$ Causes of PEM in hemodialysis patients include reduced food intake from uremia, concurrent illnesses, alterations in the balance between hunger and satiety hormones, dietary restrictions, financial limitations, depression/anxiety, and nutrient and energy losses that occur during the hemodialysis session. $^{3,4,5}$

Prevention of PEM requires a multidisciplinary effort involving the entire health care team. Essential steps to improving nutritional status include liberalizing any dietary restrictions, encouraging food intake, providing oral nutrition supplements and offering nutritional education. However, these interventions are not always effective in helping the patient achieve their nutrition goals. In such cases, intradialytic parenteral nutrition (IDPN), which involves an intravenous infusion of essential nutrients during hemodialysis treatments, may be helpful as a component of nutritional support.

This discussion will focus on the use of IDPN for in-center maintenance hemodialysis patients, which comprise the great majority of dialysis patients in the US, and review technical aspects and administration, the appropriate selection of patients, risks and benefits, and evidence supporting its use. The use of IDPN in patients on home and peritoneal dialysis will not be covered in this report. 


\section{TECHNICAL ASPECTS}

There are two main types of IDPN. In compounded admixture-based IDPN all in one IDPN bags are mixed by a pharmacy based on individual patient needs. In commercial admixture based IDPN pre-mixed bags are provided for generic use. Of the two, commercial pre-mixed bags are far more popular since the process of compounding single bags based on specific patient needs is time consuming and adds cost. ${ }^{5}$ IDPN is administrated via intravenous infusion with an infusion pump during hemodialysis. Typically the most concentrated IDPN formula is used in order to reduce the risk of volume overload and fit the treatment within the usual time constraints of a standard hemodialysis session.

A typical IDPN infusion provides 800 to $1200 \mathrm{kcal}$ in the form of glucose, lipids, and amino acids (usually 30 to $60 \mathrm{~g}$ of the latter). ${ }^{6}$ However, some amino acids can be lost in the dialysate depending upon the hemodialysis filter used and if they have been reused. ${ }^{7}$ Electrolyte-free admixtures (i.e. without sodium, potassium, and phosphorus) are also available. ${ }^{5}$ When taking into account amino acids and calories that can be lost with each hemodialysis session (i.e. 200 to $480 \mathrm{kcal}$ energy, 10 to $12 \mathrm{~g}$ amino acids) ${ }^{8}$ not more than $3000 \mathrm{kcal}$ and $150 \mathrm{~g}$ of amino acids will be provided by IDPN with thrice weekly dialysis. Thus in a $70 \mathrm{~kg}$ patient, approximately $6 \mathrm{kcal} / \mathrm{kg} /$ day (target being 30-35 $\mathrm{kcal} / \mathrm{kg} /$ day) $)^{9,10}$ and $0.30 \mathrm{~g} / \mathrm{kg} /$ day of amino acids (target being $1.2 \mathrm{~g} / \mathrm{kg} /$ day of amino acids $)^{9,10}$ are provided by IDPN, highlighting the fact that IDPN should only be used as supplemental nutrition in patients with a spontaneous oral nutrition intake of at least 25 $\mathrm{kcal} / \mathrm{kg} /$ day and $0.9 \mathrm{~g} / \mathrm{kg} /$ day of amino acids..$^{5,9,11,12}$ 


\section{EVIDENCE SUPPORTING THE USE OF IDPN}

Several prospective randomized studies have examined the effects of IDPN on clinical endpoints. Benefits noted included improvements in anthropometric parameters and serum albumin and prealbumin levels. ${ }^{12-14}$ One human study that infused stable isotopes to assess muscle turnover during IDPN identified increases in regional and total body protein synthesis. ${ }^{15}$ However, in the largest randomized study of IDPN $(n=186)$ the addition of IDPN to oral nutritional supplementation over 1 year did not improve 2-year mortality rates, hospitalization rates, or general well-being as compared to oral supplements alone. ${ }^{16}$ Additionally, all the randomized studies have been open-label in design, which increases the opportunity for bias. Moreover, while most studies used albumin as an inclusion criterion or surrogate outcome representing nutritional improvement, albumin is primarily an indicator of inflammation or illness thus making interpretation of these studies more challenging. ${ }^{17}$ Clearly longer term prospective clinical trials with appropriate control groups are needed to identify which type of patient is most likely to benefit from IDPN. ${ }^{12}$

\section{SELECTION OF PATIENTS FOR IDPN}

The process of selecting patients for IDPN first requires identifying patients who are malnourished. Table 1 includes a list of parameters from the National Kidney Foundation Disease Outcome Quality Initiative (NKF KDOQI) that can be used to identify malnutrition. ${ }^{11}$ As the table notes each of the parameters have limitations, sometimes serious ones, when applied to the hemodialysis population. Therefore identifying PEM in 
hemodialysis patients requires a large dose of clinical judgment based on a careful history and physical examination.

Once PEM is identified IDPN should not be the initial treatment choice. Rather, encouraging increased oral nutrition or supplements like protein drinks or bars though dietary counseling and education is an important first step. Every effort should also be made to ease dietary restrictions and financial constraints that may work to limit food intake. Pharmacologic agents like megestrol and gherlin may stimulate appetite, increase albumin and weight however these drugs have not been studied systematically and large-scale prospective studies are need in hemodialysis patients. ${ }^{18,19}$ Moreover, the physician should also search for identifiable causes for PEM. A complete gastrointestinal workup is needed to make sure there are no physical or structural impediments (e.g. poor dentation, dysphagia, gastroparesis) to oral intake. Other causes of anorexia such as depression, dementia, or inadequate dialysis should also be excluded.

If despite the efforts described above a patient is unable to meet his nutritional intake goals then the option of IDPN should be discussed. ${ }^{9}$ Of note, in patients who are not meeting daily nutrition goals even with oral nutritional supplements and IDPN, placement of a feeding tube for enteral nutrition or daily total parenteral nutrition may be the appropriate next step. Another subgroup of hemodialysis patients in whom enteral nutrition or total parenteral nutrition may be beneficial are critically ill individuals. These persons should be treated as intensive care patients. ${ }^{9}$ 
Several nephrology and nutrition societies have commented on the management of PEM, including the use of intensive nutritional counseling, dietary oral supplements, and IDPN as shown in Table 2 and the Figure. NKF KDOQI guidelines recommend using IDPN in malnourished dialysis patients who are not able to increase oral ingestion with dietary counseling, do not tolerate oral supplementation or enteral tube feeding, and have a sufficient spontaneous intake that combined with the nutrients provided by IDPN can reach the nutritional targets. ${ }^{11}$ ESPEN guidelines suggest using IDPN in malnourished dialysis patients who failed nutrition counseling and oral nutrition supplements. ${ }^{9}$ Interestingly, NKF KDOQI recommends IDPN only after enteral nutrition fails while ESPEN recommends IDPN as first line therapy as placement of a feeding tube is deemed to be higher risk than IDPN. In contrast, ASPEN does not recommend IDPN due to lack of adequate supporting data. ${ }^{10}$ These conflicting recommendations highlight the need for clinical judgment in determining which patients may benefit from IDPN.

When should IDPN be discontinued once initiated? Stopping is reasonable if there is sustained improvement in nutritional parameters, if adverse effects of IDPN are observed (see next section), or if there is spontaneous improvement of caloric/protein intake thus making IDPN unnecessary. On the other hand, lack of improvement after 3 to 6 months of IDPN should also lead to discontinuation of the IDPN. ${ }^{5}$ Ultimately the decision to discontinue IDPN, like the decision to initiate it, is based primarily on clinical judgment.

\section{RISKS AND ADVANTAGES OF IDPN}


There are several benefits and drawbacks of IDPN, all of which are listed in Table 3. Of particular interest in the known drawbacks are associated metabolic and electrolyte derangements. For example, IDPN is contraindicated if triglyceride levels are greater than $300 \mathrm{mg} / \mathrm{dl}$ because lipids present in the IDPN could exacerbate hypertriglyceridemia. Hyperglycemia has also been identified as a possible complication of IDPN. Because of the risk of electrolyte disturbances, stringent monitoring of the electrolytes, especially during the first weeks of IDPN support is highly recommended. ${ }^{9}$ Depending on the compounding of the nutrient solution blood glucose, triglycerides and liver function tests need to be monitored on a routine basis. ${ }^{20}$ Overall IDPN has been demonstrated in hemodialysis patients to be safe with a low complication rate. In the largest randomized study of IDPN ever performed the most common adverse effects identified were digestive symptoms, hypotension and muscle cramps that occurred during treatment, but they occurred at a similar rate as in the control group (which was consuming oral supplementation). ${ }^{16}$

\section{CONCLUSION}

ESRD patients are at risk for PEM which is linked to a greater likelihood of adverse clinical outcomes. ${ }^{4}$ IDPN is a relatively safe and efficacious option for delivering nutrients to hemodialysis patients with reduced spontaneous oral intake. However, it is not designed to be the only or even the major source of nutritional sustenance. It is also not indicated for severely malnourished or critically ill hemodialysis patients. There are no studies demonstrating that IDPN improves major clinical outcomes though few randomized trials in this field exist. ${ }^{21}$ Therefore additional studies are needed to establish 
the benefits of IDPN. In the meantime, clinical judgment and acumen remains key to diagnosing PEM and determining the need for IDPN. 


\section{REFERENCES}

1. Kopple JD. McCollum Award Lecture, 1996: protein-energy malnutrition in maintenance dialysis patients. The American journal of clinical nutrition 1997;65:154457.

2. Kalantar-Zadeh K, Block G, McAllister CJ, Humphreys MH, Kopple JD. Appetite and inflammation, nutrition, anemia, and clinical outcome in hemodialysis patients. The American journal of clinical nutrition 2004;80:299-307.

3. Gracia-Iguacel C, Gonzalez-Parra E, Perez-Gomez MV, et al. Prevalence of protein-energy wasting syndrome and its association with mortality in haemodialysis patients in a centre in Spain. Nefrologia : publicacion oficial de la Sociedad Espanola Nefrologia 2013;33:495-505.

4. Kalantar-Zadeh K, Rhee C, Sim JJ, Stenvinkel P, Anker SD, Kovesdy CP. Why cachexia kills: examining the causality of poor outcomes in wasting conditions. Journal of cachexia, sarcopenia and muscle 2013;4:89-94.

5. Sabatino A, Regolisti G, Antonucci E, Cabassi A, Morabito S, Fiaccadori E. Intradialytic parenteral nutrition in end-stage renal disease: practical aspects, indications and limits. Journal of nephrology 2014;27:377-83.

6. Cano N. Nutritional supplementation in adult patients on hemodialysis. Journal of renal nutrition : the official journal of the Council on Renal Nutrition of the National Kidney Foundation 2007; 17:103-5.

7. Ikizler TA, Flakoll PJ, Parker RA, Hakim RM. Amino acid and albumin losses during hemodialysis. Kidney international 1994;46:830-7. 
8. Liu Y, Xiao X, Qin DP, et al. Comparison of Intradialytic Parenteral Nutrition with Glucose or Amino Acid Mixtures in Maintenance Hemodialysis Patients. Nutrients $2016 ; 8$.

9. Cano NJ, Aparicio M, Brunori G, et al. ESPEN Guidelines on Parenteral Nutrition: adult renal failure. Clinical nutrition 2009;28:401-14.

10. Brown RO, Compher C. A.S.P.E.N. clinical guidelines: nutrition support in adult acute and chronic renal failure. JPEN Journal of parenteral and enteral nutrition 2010;34:366-77.

11. Clinical practice guidelines for nutrition in chronic renal failure. K/DOQI, National Kidney Foundation. American journal of kidney diseases : the official journal of the National Kidney Foundation 2000;35:S1-140.

12. Dukkipati R, Kalantar-Zadeh K, Kopple JD. Is there a role for intradialytic parenteral nutrition? A review of the evidence. American journal of kidney diseases : the official journal of the National Kidney Foundation 2010;55:352-64.

13. Cano N, Labastie-Coeyrehourq J, Lacombe P, et al. Perdialytic parenteral nutrition with lipids and amino acids in malnourished hemodialysis patients. The American journal of clinical nutrition 1990;52:726-30.

14. Marsen TA, Beer J, Mann H. Intradialytic parenteral nutrition in maintenance hemodialysis patients suffering from protein-energy wasting. Results of a multicenter, open, prospective, randomized trial. Clinical nutrition 2017;36:107-17.

15. Pupim LB, Flakoll PJ, Ikizler TA. Nutritional supplementation acutely increases albumin fractional synthetic rate in chronic hemodialysis patients. Journal of the American Society of Nephrology : JASN 2004;15:1920-6. 
16. Cano NJ, Fouque D, Roth $\mathrm{H}$, et al. Intradialytic parenteral nutrition does not improve survival in malnourished hemodialysis patients: a 2-year multicenter, prospective, randomized study. Journal of the American Society of Nephrology : JASN 2007;18:2583-91.

17. Friedman AN, Fadem SZ. Reassessment of albumin as a nutritional marker in kidney disease. Journal of the American Society of Nephrology : JASN 2010;21:223-30.

18. Yeh SS, Marandi M, Thode HC, Jr., et al. Report of a pilot, double-blind, placebo-controlled study of megestrol acetate in elderly dialysis patients with cachexia. Journal of renal nutrition : the official journal of the Council on Renal Nutrition of the National Kidney Foundation 2010;20:52-62.

19. Wynne K, Giannitsopoulou K, Small CJ, et al. Subcutaneous ghrelin enhances acute food intake in malnourished patients who receive maintenance peritoneal dialysis: a randomized, placebo-controlled trial. Journal of the American Society of Nephrology : JASN 2005;16:2111-8.

20. Druml W, Kierdorf HP. Parenteral nutrition in patients with renal failure Guidelines on Parenteral Nutrition, Chapter 17. German medical science : GMS e-journal 2009;7:Doc11.

21. Pupim LB, Flakoll PJ, Brouillette JR, Levenhagen DK, Hakim RM, Ikizler TA. Intradialytic parenteral nutrition improves protein and energy homeostasis in chronic hemodialysis patients. The Journal of clinical investigation 2002;110:483-92. 
Table 1: National Kidney Foundation Recommended Measures for Monitoring Nutritional status in Maintenance Dialysis Patients ${ }^{8}$

\begin{tabular}{|c|c|c|c|}
\hline Parameters & $\begin{array}{c}\text { Frequency of } \\
\text { Measurements }\end{array}$ & Comments & Limitations \\
\hline $\begin{array}{l}\text { Pre-dialysis serum } \\
\text { albumin }\end{array}$ & Monthly & $\begin{array}{l}\text { Target level is } \\
\text { normal }>4 \mathrm{~g} / \mathrm{dL}\end{array}$ & $\begin{array}{l}\text { Affected by non- } \\
\text { nutritional factors } \\
\text { like inflammation, } \\
\text { dehydration, } \\
\text { infection, acid-base } \\
\text { status }\end{array}$ \\
\hline $\begin{array}{l}\% \text { change in post } \\
\text { dialysis body weight }\end{array}$ & Monthly & $\begin{array}{l}\text { Trends from edema } \\
\text { free body weight } \\
\text { needs to be } \\
\text { monitored }\end{array}$ & $\begin{array}{l}\text { Getting a true dry } \\
\text { weight may be } \\
\text { challenging }\end{array}$ \\
\hline $\begin{array}{l}\text { Subjective global } \\
\text { assessment }\end{array}$ & Every 6 months & $\begin{array}{l}\text { A simple technique } \\
\text { based on subjective } \\
\text { and objective } \\
\text { aspects of the } \\
\text { medical history and } \\
\text { physical } \\
\text { examination }\end{array}$ & $\begin{array}{l}\text { Does not include } \\
\text { visceral protein } \\
\text { levels in the } \\
\text { assessment. It is } \\
\text { subjective and has } \\
\text { not been studied } \\
\text { well in hemodialysis } \\
\text { population }\end{array}$ \\
\hline $\begin{array}{l}\text { Dietary interview } \\
\text { and/or dairy }\end{array}$ & Every 6 months & $\begin{array}{l}\text { 3-day dietary } \\
\text { records followed by } \\
\text { interviews and } \\
\text { calculating nutrient } \\
\text { intake by an } \\
\text { experienced } \\
\text { registered renal } \\
\text { dietitian }\end{array}$ & $\begin{array}{l}\text { Time consuming } \\
\text { and limited by } \\
\text { accuracy of } \\
\text { documentation by } \\
\text { patient and/or } \\
\text { interview and } \\
\text { calculation by } \\
\text { dietician }\end{array}$ \\
\hline $\begin{array}{l}\text { Normalized protein } \\
\text { nitrogen appearance } \\
\text { (nPNA) }\end{array}$ & Monthly & $\begin{array}{l}\text { In the clinically } \\
\text { stable patient, nPNA } \\
\text { can be used to } \\
\text { estimate protein } \\
\text { intake. }\end{array}$ & $\begin{array}{l}\text { nPNA is not valid in } \\
\text { catabolic or } \\
\text { anabolic state. } \\
\text { nPNA may fluctuate } \\
\text { from day to day as a } \\
\text { function of protein } \\
\text { intake, and a single } \\
\text { nPNA measurement } \\
\text { may not reflect } \\
\text { usual protein } \\
\text { intakes. }\end{array}$ \\
\hline
\end{tabular}




\section{Table 2: Society Recommendations on Indications for IDPN}

\begin{tabular}{|l|l|}
\hline KDOQI, 200011 & $\begin{array}{l}\text { 1. Evidence of protein or energy malnutrition and inadequate dietary } \\
\text { protein and/or energy intake } \\
\text { 2. Inability to administer or tolerate adequate oral nutrition, including } \\
\text { food supplements or tube feeding } \\
\text { 3. Oral or enteral intake which, when combined with IDPN, meets the } \\
\text { recommended dietary intake }\end{array}$ \\
\hline ESPEN, 20099 & $\begin{array}{l}\text { 1. IDPN improves nutritional status in undernourished hemodialysis } \\
\text { patients. } \\
\text { 2. In outpatients, if nutritional counseling and oral nutritional } \\
\text { supplements are unsuccessful, IDPN should be proposed }\end{array}$ \\
\hline ASPEN, 2010 & $\begin{array}{l}\text { IDPN should not be used as a nutritional supplement in malnourished } \\
\text { chronic kidney disease stage 5 hemodialysis patients. }\end{array}$ \\
\hline
\end{tabular}

KDOQI, Kidney Disease Outcomes Quality Initiative; ESPEN, European Society of Parenteral and Enteral Nutrition; ASPEN, American Society of Parenteral and Enteral Nutrition 
Table 3: Advantages and Disadvantages of IDPN

\begin{tabular}{|l|l|}
\hline Advantages & $\begin{array}{l}\text { 1. No need for a dedicated enteral feeding tube or total parenteral } \\
\text { nutrition vascular access }\end{array}$ \\
& $\begin{array}{l}\text { 2. Ultrafiltration during dialysis will help minimize the risks of fluid } \\
\text { overload }\end{array}$ \\
3. No demands on patient time or effort
\end{tabular}


Figure: Flowchart for nutritional intervention in hemodialysis patients with protein energy malnutrition

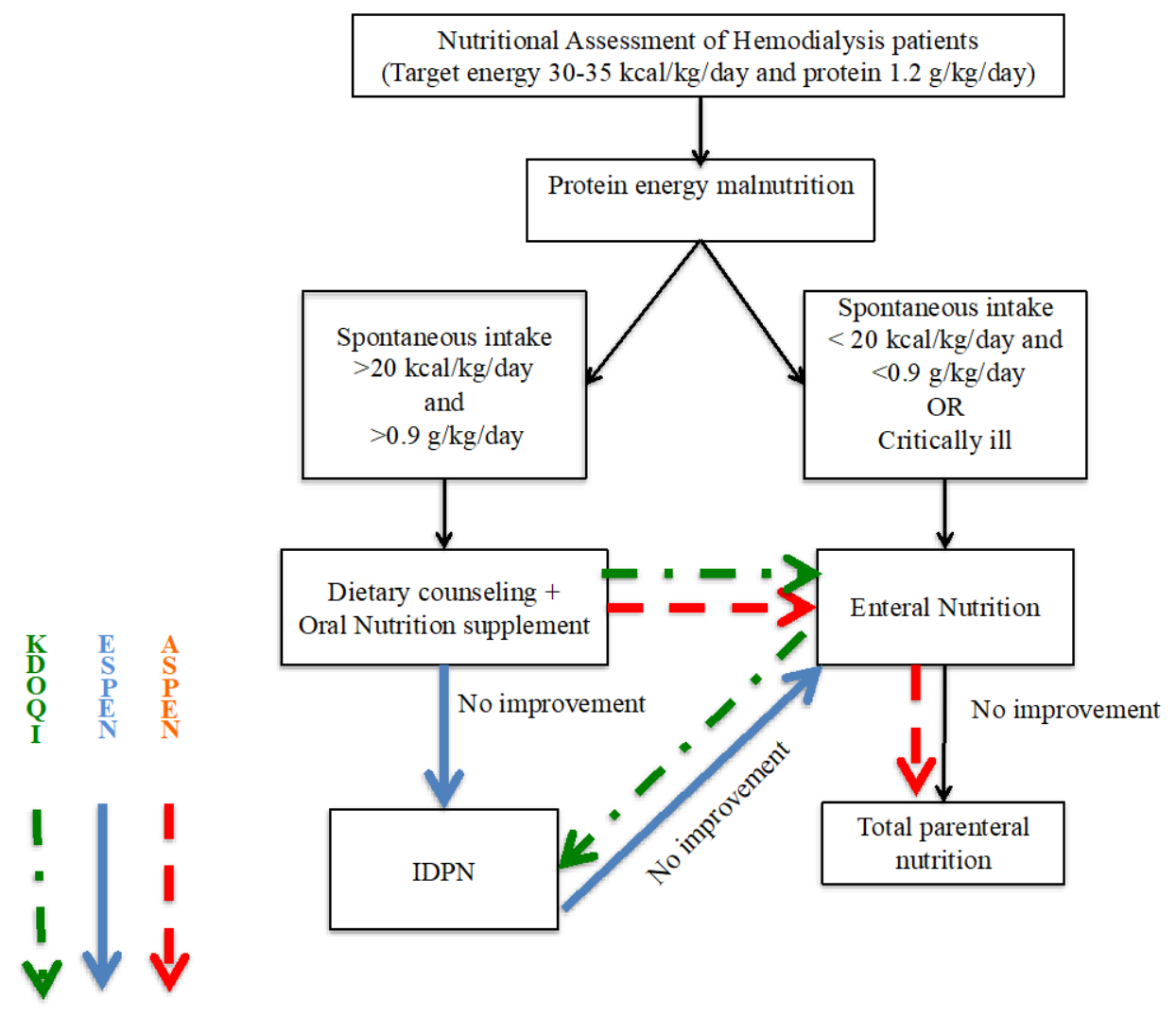

